Grand Valley State University

ScholarWorks@GVSU

$12-2005$

\title{
Women's Representation and Status in Law Enforcement: Does CALEA Involvement Make a Difference?
}

David Burlingame

Grand Valley State University, burlingd@gvsu.edu

Agnes L. Baro

Valdosta State University

Follow this and additional works at: https://scholarworks.gvsu.edu/scjpeerpubs

Part of the Criminology and Criminal Justice Commons

\section{ScholarWorks Citation}

Burlingame, David and Baro, Agnes L., "Women's Representation and Status in Law Enforcement: Does CALEA Involvement Make a Difference?" (2005). Peer Reviewed Publications. 1.

https://scholarworks.gvsu.edu/scjpeerpubs/1

This Article is brought to you for free and open access by the School of Criminology, Criminal Justice, and Legal Studies at ScholarWorks@GVSU. It has been accepted for inclusion in Peer Reviewed Publications by an authorized administrator of ScholarWorks@GVSU. For more information, please contact scholarworks@gvsu.edu. 


\title{
Women's Representation and Status in Law Enforcement: Does CALEA Involvement Make a Difference?
}

\author{
David Burlingame \\ Grand Valley State University
}

Agnes L. Baro

Valdosta State University

\begin{abstract}
This study's objective was to determine if involvement in the Commission on Accreditation for Law Enforcement Agencies (CALEA) accreditation process will have a significant, positive effect on the representation of sworn women in large police agencies at all organizational levels and on the representation of women of color as a percentage of the total workforce. This study compared 193 large (100 or more sworn personnel) non-CALEA agencies with 201 large CALEA agencies. Results of this research suggest that there are significant differences between CALEA and non-CALEA agencies and that involvement in the CALEA accreditation process appears to encourage and facilitate the recruitment and promotion of women at least in large police agencies. Additional research should be conducted comparing small CALEA and non-CALEA agencies, and the authors recommend CALEA officials revisit the available workforce issue to ensure more accurate estimates of the numbers of women in respective workforces.
\end{abstract}

Keywords: CALEA; female; minority

According to the National Center for Women and Policing (NCWP; 2002), women are only about $11 \%$ of all state, municipal, and county police officers. Over the past 30 years, civil rights acts, lawsuits, and affirmative

AUTHORS' NOTE: We thank the Commission on Accreditation for Law Enforcement Agencies and the National Center for Women and Policing and dedicate this work to the memory of Sgt. William Michael Crooke.

Criminal Justice Policy Review, Volume 16, Number 4, December 2005 391-411

DOI: $10.1177 / 0887403405275319$

(C) 2005 Sage Publications 
action campaigns have increased women's representation in law enforcement by only about half of one percent per year (p. 2).

There is, however, a great deal of variation in the percentages of women officers in different types of police agencies. For example, in some of the larger municipal and county agencies, women are more than $20 \%$ of all officers; however, among state police departments, they are only $5.9 \%$ of the sworn personnel (NCWP, 2002, p. 5; Van Wormer \& Bartollas, 2000, p. 161). Employment discrimination lawsuits ending in consent decrees also produce variation. Agencies that operate under consent decrees or other types of court scrutiny have higher percentages of sworn women (NCWP, 2003, p. 3). Finally, and of most interest in the current study, agencies involved in the process to obtain or retain accreditation from the Commission on Accreditation for Law Enforcement Agencies (CALEA) may also have higher percentages of women officers.

To receive CALEA accreditation, an agency whose sworn workforce is not in "approximate proportion" to the ethnic and gender makeup of the available workforce in the community it serves must have an equal opportunity plan and an affirmative action recruitment plan (CALEA, 1999). These standards do not, however, mandate achieving a demographically representative workforce. Instead, they stress the importance of making good faith efforts to do so. The major question in the current study was what effect (if any) do these mandatory standards have on the percentages of sworn women at the line, supervisory, and command levels? The current study also attempted to assess the effectiveness of the standards in terms of the percentages of officers who are women of color (i.e., are counted by law enforcement agencies as African American, Hispanic, or Other).

\section{LITERATURE REVIEW}

There is a substantial amount of research literature in support of CALEA's affirmative action standards and of policies directed toward increasing female representation within police departments. For example, Lonsway, Wood, and Spillar (2002) examined data from studies of the Los Angeles and Cincinnati police departments and found that "the average male officer on a big city police agency costs taxpayers somewhere between two-and-a-half and five-and-a-half times more than the average woman officer in excessive force liability lawsuit payouts" (p. 60). Similarly, Harrington and Lonsway (as cited in Price and Sokoloff, 2003) reviewed the literature on officer effectiveness and reported that women are often better at defusing potentially violent situations, have fewer citizen com- 
plaints lodged against them, and appear to be more supportive of community policing efforts than male counterparts.

The most important piece of literature relied on in the current study is the fifth annual report produced by the NCWP (2002). Titled Equality Denied: The Status of Women in Policing: 2001, this report was based on surveys of large, small, and rural police agencies. Large agencies were defined as those employing 100 or more officers. Small and rural agencies were those located in counties with populations under 50,000 and employing fewer than 100 officers (NCWP, 2002, p. 12). The large agency survey was conducted using a stratified, random sample of 360 agencies; 247 (69\%) responded and were included in the final report.

Another survey, using a random sample of 384 small and rural agencies, was also conducted. One of the major findings from these surveys was that although women hold $12.7 \%$ of the sworn positions in large agencies, they represent only $8.1 \%$ of the officers in small and rural agencies. Combining these figures and using a weighted estimate, we found that (nationwide) women are only about $11.2 \%$ of all police officers (NCWP, 2002, pp. 1-4).

Other major findings from the surveys were that women of color are only $4.8 \%$ of officers in large agencies and, at $1.2 \%$, are practically invisible in small and rural agencies. In large agencies, women of color also hold less than $1 \%$ of the command positions. In addition, more than one half of the large agencies reported that there were no women in their command positions; $97.4 \%$ of the small and rural agencies reported a similar lack of female commanders (NCWP, 2002, p. 4). With regard to progress since 1972 (the year Congress made sex discrimination employment laws applicable to public sector employers), the surveys revealed that the one half of $1 \%$, per year growth rate had slowed, and during the past few years the percentage of female officers in large departments has actually declined (NCWP, 2002, p. 2).

In the spring of 2003, the NCWP published another study. This time they focused on the effect of consent decrees. Key findings from this study are that consent decrees do have a significant, positive effect on increasing female representation regardless of the type (i.e., city, county, or state) of law enforcement agency. However, the study also revealed that when the agencies were no longer under consent decrees the less than one half of $1 \%$ per year rate at which they increased female representation declined by one half (NCWP, 2003, p. 3).

The NCWP (2003) concluded that consent decrees, or other negotiated or court-ordered reforms, are vitally important to the progress of women in policing. 
More than 10 years earlier, Martin (1991) conducted a similar study and reached a similar conclusion. Martin (1991) found that voluntary affirmative action plans and court-ordered recruiting policies had significant, positive impacts on the hiring and promotion of female police officers. She also noted that a series of conservative decisions made by the Supreme Court during the 1980s made it much more difficult for women to prevail in sex discrimination lawsuits and much easier for opponents to challenge affirmative action plans (Martin, 1991, p. 503). It appears as though this trend has continued.

According to the NCWP $(2002,2003)$, there were very few consent decrees negotiated or imposed during the mid- to late 1990s. Zhao, Herbst, and Lovrich (2001) examined data from a representative sample of all police agencies with service communities of 25,000 or more citizens and found that less than one half had informal or formal affirmative action programs. These authors also discovered that formal, affirmative action programs are particularly important in terms of increased percentages of African American policewomen.

If women are to make any substantial progress in police representation, retention, and promotion, it appears as though outside pressure will be vitally important. Police agencies are, however, notoriously resistant to outside pressure. Belknap and Shelly (1992) noted that police have a long history of resisting outside pressures to increase the numbers of female officers. This may be why accreditation could be a more promising route to increasing the numbers of women in law enforcement. Accreditation is a voluntary process. Although it involves the imposition of so-called outside standards and inspections, accreditation is typically a process that is heavily supported by top-level management. Before discussing CALEA accreditation, however, there is a need to further explore the literature on the difficulties of recruiting, retaining, and promoting policewomen.

\section{Recruitment}

There appears to be a perception among law enforcement officials that the current labor market is tight or difficult in terms of recruiting qualified applicants, especially women and minorities (Domash, 2002; Sanow, 2001). It is a perception that is, most likely, based on their experiences; however, it is questionable given what economists are reporting about the labor market. A. Bernstein (2003) summarized these reports in an article about the erosion of good-paying jobs with benefits. He pointed out that during the past decade, millions of jobs paying wages well below the pov- 
erty line have been created whereas good-paying, career-ladder jobs, with benefits, have become a scarce resource. Meanwhile, women and minorities are the fastest growing groups in the low-wage labor market. Approximately $40 \%$ of them have high school educations, and they tend to be younger women (J. Bernstein \& Hartmann, 1999). Applebaum, Bernhardt, and Murnane (2003) added that the size of the low-wage labor market is approximately 34 million men and women (about $24 \%$ of the entire U.S. workforce) and that the lack of a college degree is a major barrier to the upward mobility of many of these workers. However, only about $1 \%$ of the nation's police departments require applicants to have 4-year degrees (Baro \& Burlingame, 1999; Hickman \& Reaves, 2003). Similarly, Baumol, Blinder, Wolff, and May (2003) noted that American workers most affected by longterm downsizing are those who do not have relatively sophisticated, technological skills.

These workers also expand the labor pool from which police can draw because with the possible exception of some basic computer skills, entrylevel police jobs do not require technological experience.

The recruitment of women and minorities is also enhanced by changes in police attitudes. Gossett and Williams (1998) described the legal battles of the 1970s and 1980s wherein many police administrators refused to adhere to affirmative action guidelines unless they were threatened by lawsuits. Conversely, a late 1990s survey of 800 police chiefs, conducted by the International Association of Chiefs of Police (1998), revealed that $70 \%$ agreed that the number of female officers should be increased. Approximately $80 \%$ of the chiefs also expressed interest in getting training in the recruitment and retention of female officers. Similarly, Prussel and Lonsway (2001) provided considerable evidence of a sincere interest among most law enforcement executives in increasing representation of minorities and women.

Changes in the size and nature of the potential police labor pool and in more positive police attitudes about women do not, however, overcome what might be the most serious recruiting problem. This is what Gold (2000) called the "image problem" (p. 160). Stereotypical images of police as macho crime fighters who spend most of their time in high-speed pursuits, shoot-outs, and other forms of combat discourage women from even considering careers in law enforcement. Unfortunately, these images are not just products of movies and television, they are also produced and promoted by police themselves (Gold, 2000; Lonsway, 2001).

In addition to the aforementioned distorted images of everyday law enforcement, the NCWP (2001) pointed out that job descriptions and job announcements continue to emphasize physical attributes over other skills 
such as communication and mediation. Textual description of crime fighting (even this term has heavy male, military overtones) coupled with visual images of the same genre may discourage qualified women from applying for law enforcement positions. Those who are not discouraged and are hired face another formidable barrier in the police academy.

Most police academies in the United States still use a military boot camp approach to training. This type of training emphasizes "tearing down individuals and rebuilding them to the military model" (NCWP, 2001, p. 83). Bailey and Kingshott (2004) pointed out that academy training recruits are

often yelled at, humiliated before their peers, called names, and punished for any evidence of weakness. Their success and graduation may depend upon not only their skills, but also their ability to tolerate such humiliation and to relinquish any appearance of personal identity. (p. 195)

This entire process is, according to the NCWP (2001), "a culture foreign to most female recruits" (p. 83).

Police academies also reinforce the previously described visual and textual description of police work by emphasizing physical and fire arms training. For example, the current academy curriculum in Michigan, which is mandated by the Michigan Commission on Law Enforcement Standards, requires that a full $40 \%$ of the 562 training hours be devoted to firearms ( 72 hours), combative physical skills ( 77 hours), emergency vehicle operation ( 32 hours), and physical fitness (44 hours). In contrast, recruits receive only 8 hours of interpersonal skills training, and 2 hours of civil rights and human relations training. These authors believed that this overemphasis on physical skills, coupled with the boot camp style of training results in qualified female candidates either not applying for law enforcement positions or dropping out at the academy level.

The continued harassment of policewomen is another problem that impedes recruitment because it helps sustain organizational reputations for not welcoming women (Gold, 2000; Van Wormer \& Bartollas, 2000). Women who might want to be police officers are discouraged by this reputation. In the words of one female criminal justice student: "Why would I go into policing? I'd rather work someplace where I'm wanted." Stereotypical images, created inside and outside police departments, of women who are or want to be police officers also have a negative impact on recruiting. Such images include characterizing these women as unfeminine, too aggressive, deviant, "bitchy," and "castrating" (Gold, 2000, p. 160; Grennan, 2000). Thus, an essential part of the recruiting process must be to convince 
women that they are welcome and will have the full support of the police organization.

Images of the police in communities of specific minorities may also amplify difficulties associated with recruiting women of color. As Martin (1994) and Dodge and Pogrebin (2001) noted, police are often viewed as oppressors and treated with suspicion and hostility in many communities of minorities. As a result, images of police as sexist and racially oppressive may make recruiting women of color even more difficult.

\section{Retention}

According to the results of the previously mentioned International Association of Chiefs of Police (1998) survey, police departments have more trouble retaining women than men. Some of this trouble might be attributed to ongoing harassment or other types of hostility (Horne, 1999; Lonsway \& Campbell, 2002; Van Wormer \& Bartollas, 2000); however, family problems must also be considered. Shift work and other job-related issues make raising families a difficult process. Van Wormer and Bartollas (2000) pointed out that the burden of child care and domestic duties often fall more heavily on the female officers (p. 168). Lonsway and Campbell (2002) also insisted that departments without adequate family leave or pregnancy provisions are more likely to experience higher attrition rates.

Bennett and Hess (2004) insisted that poor working conditions and inflexible schedules are a major source of job dissatisfaction and turnover. Poor ventilation and lighting and/or inadequate heating systems all have serious impacts on job morale. Warrell (2000) added that equipment deficiencies can also lower morale and retention rates. Such deficiencies may affect women more heavily than men. For example, Polisar and Milgrim (1998) noted that many female officers have to contend will ill-fitting uniforms and equipment because some departments do not order from companies that carry women's sizes. Because they are often single mothers, inflexible scheduling can also have more impact on female officers. Some of the larger departments are providing more flexible scheduling options including job-sharing opportunities. Larger departments are also more likely to be actively involved in addressing child care issues such as a lack of 24-hour day care centers. However, smaller departments may not have the resources or the support from local governments to initiate similar retention strategies.

In a review of the scant literature on African American policewomen, Dodge and Pogrebin (2001) noted the ways in which race and gender come 
together as status variables to promote exclusion. This literature suggests that Black women are most likely to be excluded from informal police networks and that Black men and White women tend to leave them isolated by aligning themselves with the White, male majority (Dodge \& Pogrebin, 2001).

In an earlier study, Martin (1994) concluded that African American policewomen experience less protection and greater amounts of hostility and intimidation. Felkenes and Schroeder (1993) identified active discrimination against minority women as an important explanation for higher rates of training academy attrition; however, there is no similar research on posttraining attrition.

\section{Promotion}

Although retention and promotion are intrinsically linked, addressing some of the promotional barriers facing women is warranted. Gender differences in types of job experience may be one of these barriers. Polk and Armstrong (2001) found that job experience is the best predictor of police promotion and that women were "over represented in assignments identified and 'other' which often are not recognized as 'real' police work" (p. 90).

More important, they also found that although 59\% of women began their careers in patrol, $82 \%$ of men began their careers in patrol. The traditional career paths in law enforcement agencies begin in patrol, progressing to first-line supervisor, for example, patrol sergeant, then lieutenant, captain, and so on. This pattern held in Polk and Armstrong's (2001) study. They reported that "traditionally, an officer would have to be promoted through the ranks of sergeant and lieutenant before attaining the managerial rank of captain" (Polk \& Armstrong, 2001, p. 86). This process puts women at a disadvantage for promotional opportunities given that such a high percentage are not assigned to the important first step in patrol. Horne (1999) reviewed the literature on policewomen and promotion and agreed that previous assignments and training are critically important.

Of course, it should be noted that policewomen often volunteer for socalled other assignments such as special drug education, school, or community liaison work. Such volunteerism can be explained by previously mentioned child care and family responsibilities that can also lead to women not even applying for promotion because they know their schedules will change and become less predictable. 
Finally, the International Association of Chiefs of Police (1998) conducted a large survey on the future of women in law enforcement and found that women who work in departments actively involved in recruiting women are more likely to seek promotion. If involvement in the CALEA accreditation process encourages the recruitment of women, it is entirely possible that these so-called CALEA agencies will have higher percentages of women at the line, supervisory, and command levels.

\section{CALEA}

CALEA was formed in 1979 through a joint effort by law enforcement's major membership associations: the International Association of Chiefs of Police, The National Organization of Black Law Enforcement Executives, The National Sheriffs' Association, and The Police Executive Research Forum. The goal was to establish a body of standards designed to (a) "increase law enforcement agency capabilities to prevent and control crime"; (b) "increase agency effectiveness and efficiency in the delivery of law enforcement services"; (c) "increase cooperation and coordination with other law enforcement agencies and with other agencies of the criminal justice system"; and (d) "increase citizen and employee confidence in the goals, objectives, policies, and practices of the agency" (CALEA, 1999, p. xiii). In addition, the accreditation process was to be designed to afford law enforcement agencies the opportunity to voluntarily demonstrate that they meet an established set of professional standards.

The commission comprises 21 members, 11 from law enforcement affiliates and 10 from private and public sectors. Currently there are more than 1,600 public safety agencies in the United States, Canada, Barbados, and Mexico with CALEA accreditation or in the accreditation process. Approximately $24 \%$ of all full-time state and local law enforcement officers in the United States work for such agencies (S. Mitchell, program manager, CALEA, personal communication, March 9, 2004). Once an agency is accredited, it must be reaccredited every 3 years. This process involves onsite examinations by CALEA assessors during which the agencies must provide proof of compliance with all applicable standards.

There are currently 445 standards that address a wide range of operational and administrative issues. Many of these standards are mandatory (depending on the agency size and field of operations); however, agencies must also be in compliance with $80 \%$ of the optional standards. The chapters pertaining to recruitment, selection, and promotion consist of 33 stan- 
dards, of which 31 are mandatory for all agencies. We concentrate on three standards from chapter 31, Recruitment; however, standards in the chapters covering selection and promotion are also pertinent and are discussed.

Standard 31.2.1 requires "The agency has ethnic and gender composition in the sworn law enforcement ranks in approximate proportion to the makeup of the available workforce in the law enforcement agency's service community, or a recruitment plan pursuant to standard 31.2.2" (CALEA, 1999, chap. 31, p. 1). In complying with this standard the agency must gather demographic information concerning the available workforce and compare it to the demographic composition of its own, sworn workforce. The U.S. Census Bureau (2002) defined the term available workforce as a "combination of the employed and experienced unemployed" in a particular area or region (para. 2). There are four census regions (North, South, East, and West) further divided into nine census divisions. As is discussed in the Method section, the current study also compares the percentages of sworn women within the nine divisions among CALEA versus nonCALEA agencies.

Available workforces vary from agency to agency by ethnic differences as well as by differences in requirements for employment. For example, an agency requiring a 4-year college degree to meet the minimum educational level would have a different available workforce than one requiring a high school diploma. Agencies seeking accreditation or reaccreditation should first take into account all of their hiring requirements then apply them to the population in their service area to arrive at a credible estimate of the available workforce. There are, however, at least two problems associated with obtaining the data necessary to produce this estimate.

First, many local law enforcement agencies are required to follow city or county affirmative action plans based on available workforce data that may or may not accommodate minimum requirements for police employment. Second, it is not always possible to obtain appropriately detailed census or labor force data. For example, the year 2000, U.S. Census Bureau's "Special Equal Opportunity File" provides multiracial, available workforce data only for geographic areas with populations exceeding 50,000 people. "This means that over two-thirds of the counties in the U.S. are not identified separately on the EEO [equal employment opportunity] file but are combined with other counties" (U.S. Census Bureau, 2002, para. 7). CALEA recognizes the difficulties agencies have in obtaining sound workforce data. With regard to the availability of women in a local workforce, the instructions on the CALEA "Agency Demographic Report" includes a statement that "In the absence of reliable local data on available females, you may use the 
national average of $14 \%$ cited by the National Association of Women Law Enforcement Executives (NAWLEE) or a comparison with similar law enforcement agencies" (CALEA accreditation form number $6 \mathrm{~A}$ ).

If an agency is found not to have a sworn workforce in approximate proportion to its available workforce, then it must be in compliance with Standard 31.2.2 that states,

The agency has a recruitment plan for sworn personnel that includes the following elements (a) statement of objectives; (b) plan of action designed to achieve the objectives identified in bullet (a); and (c) procedures to periodically evaluate the progress toward objectives and revise/reissue the plan.

(CALEA, 1999, chap 31, p. 2)

This standard compels the agency to develop a recruitment plan designed to focus on the disparity between the available workforce and the makeup of its sworn workforce. However, the standard requires more than just a plan, it also requires a plan of action to meet the objectives and a procedure to evaluate progress toward meeting the objectives. This ensures that the agency will not just have a paper plan in place with no objectives or means of measuring achievement.

The last standard we focus on in recruitment is 31.2.3: "The agency has an equal employment opportunity plan" (CALEA, 1999, chap. 31, p. 2). The guidelines for the development and implementation of this plan include a strongly worded statement from the agency's CEO ensuring all individuals be given equal opportunity for employment, a process for filing complaints relating to equal employment opportunity, and specific action steps the agency should take to ensure equal employment opportunity is a reality (CALEA, 1999, chap. 31, p. 2). As previously noted in Standard 31.2.2, the critical element is the specific action step guidelines. Instead of just stating the agency is an equal opportunity employer, the agency needs a plan that objectively demonstrates its commitment to equal opportunity.

Although our focus is on the three aforementioned standards found in the Recruitment chapter, other standards address previously discussed problems in hiring and retaining females and or minorities. For example, in chapter 32, Selection, Standard 32.1.2 addresses the problem of job-related qualifications by requiring the following. "All elements of the selection process for sworn personnel use only those rating criteria or minimum qualifications that are job related" (CALEA, 1999, chap. 31, p. 1). Accredited agencies or those seeking accreditation cannot employ a selection process that includes criteria that will disqualify potential applicants through the application of non-job-related criteria. 
As we indicate, promotional opportunities play a significant role in the retention of females and minorities. Chapter 34, Promotion, contains a significant standard related to promotional opportunities. Standard 34.1.4 states, "All elements used to evaluate candidates for sworn personnel for promotion are job-related and nondiscriminatory" (CALEA, 1999, chap. 34, p. 2). This standard provides insurance that promotional criteria will not favor any particular segment of an agency and that there will be a level promotional field on which women and minorities can compete.

Although one could argue that all of these required plans and methods of operation can be produced on paper, and appear to meet the requirements, it is important to remember the agency must prove its policies are in compliance with the standards and that they are following their policies. This compliance is verified by outside assessors who physically visit and inspect each agency initially and every 3 years thereafter.

\section{METHOD}

Although the NCWP (2002) study included large and small and/or rural police agencies, the current study is limited to comparisons between large (i.e., those employing 100 or more sworn officers) agencies involved in the CALEA accreditation process and large agencies included in the NCWP study report who are not involved in this process. This is because NCWP did not publish detailed, descriptive data on the small and/or rural agencies. Instead, they provided a summary of the small and/or rural agency data, and we do not know what percentage of these agencies might be CALEA agencies. For this reason, and even though we have comprehensive small and/or rural agency CALEA data, we are deferring small and/or rural agency comparisons until we can obtain appropriate comparison data.

The purpose of the large agency comparisons is to determine what (if any) effect CALEA involvement may have on the representation of women as a percentage of the total sworn workforce and as percentages of officers in line, supervisory, and command positions. In addition, the current study also attempted to determine whether CALEA involvement might be associated with higher percentages of the sworn, large agency, workforce being women of color. For the purposes of the current study, CALEA-involved agencies will be referred to as "CALEA agencies" and those without such involvement will be referred to as "non-CALEA agencies."

It is hypothesized that involvement in the CALEA accreditation process will have a significant, positive effect on the representation of sworn 
women in large agencies at all organizational levels and on the representation of women of color as a percentage of the total sworn workforce.

\section{Data}

There are two data sources. The first is the previously described study on the status of women in policing (NCWP, 2002). The second is CALEA report data. In response to our request on data about the status of women, CALEA officials launched a project to computerize their report data and made the collection of data on women the first phase of this project. Within 6 months, we had a relevant database on 201 large and 268 small and/or rural CALEA agencies. However, and as previously indicated, the current study is limited to comparisons between large CALEA and non-CALEA agencies.

Because the NCWP data included CALEA agencies, the first task was to remove them from the list provided in their report, Appendix B (CALEA, 2002, p. 21). Of 247 agencies listed, 54 were CALEA agencies. This left 193 large agencies in the NCWP, non-CALEA data set to be compared with 201 large CALEA agencies.

Regrettably, we did not have access to the available workforce data used by the various police agencies. Prompted by an excellent suggestion from a reviewer, however, the current study does include a comparison of CALEA and non-CALEA agencies within each of the nine census divisions. All data were analyzed using the SPSS (10.0) program.

\section{Study Questions}

There are five questions about the large agencies.

Are there significant differences between CALEA and non-CALEA agencies in terms of higher percentages of women in the total sworn workforce and at the line, supervisory, and command levels?

Is there a similar, significant difference in the percentage of the sworn workforce that composed of women of color?

Are there significant differences in female representation between municipal, county, and state agencies regardless of CALEA involvement?

If there are significant differences between municipal, county, and state agencies, how do these differences compare to differences found between CALEA and non-CALEA agencies? 
For example, if there is a significant difference between city, county, and state agencies in terms of the percentage of commanders who are women, is there a similar difference between the CALEA and non-CALEA agencies?

Could any possible differences between the CALEA and non-CALEA agencies be more a function of variation in census division demographics than of CALEA involvement per se?

Although we do not have the data to make available workforce comparisons, comparisons within census divisions may shed some light on the question or, at least, prompt others to conduct further research.

\section{FINDINGS}

As indicated in Table 1, the total number of officers is higher in the nonCALEA agencies (i.e., 109,742 vs. 99,353). This difference is attributable to larger numbers of officers in the non-CALEA municipal and state agencies. CALEA county agencies had a total of 26,159 sworn officers compared to 19,877 in the non-CALEA county agencies. The difference in mean numbers of officers (568 vs. 494) suggests that the non-CALEA agencies tend to be larger. This difference was not, however, statistically significant (see Table 1).

Regardless of the type of agency (i.e., municipal, county, or state), CALEA agencies have somewhat higher percentages of women in their total sworn workforces and at the command, supervisor, and the line staff levels. The percentages of sworn women of color are also higher among the CALEA agencies. Table 1 frequencies also suggest that county agencies, whether CALEA or non-CALEA, appear to have higher percentages of women at supervisor and line staff levels. There is, however, a remarkable difference between the county agencies in that women are $10 \%$ of those at the command level in CALEA county agencies but only $4 \%$ in non-CALEA county agencies.

With regard to women's representation as a percentage of all sworn officers, the findings are similar to the NCWP (2002) findings in that only $11 \%$ of the 209,095 officers in this study were women. The means for women officers ranged from 14\%, among CALEA county agencies, to 5\% among non-CALEA state agencies.

Table 2 contains the results of a statistical comparison between the CALEA and non-CALEA agencies. A one-way ANOVA test indicated statistically significant differences in the percentages of officers who are 


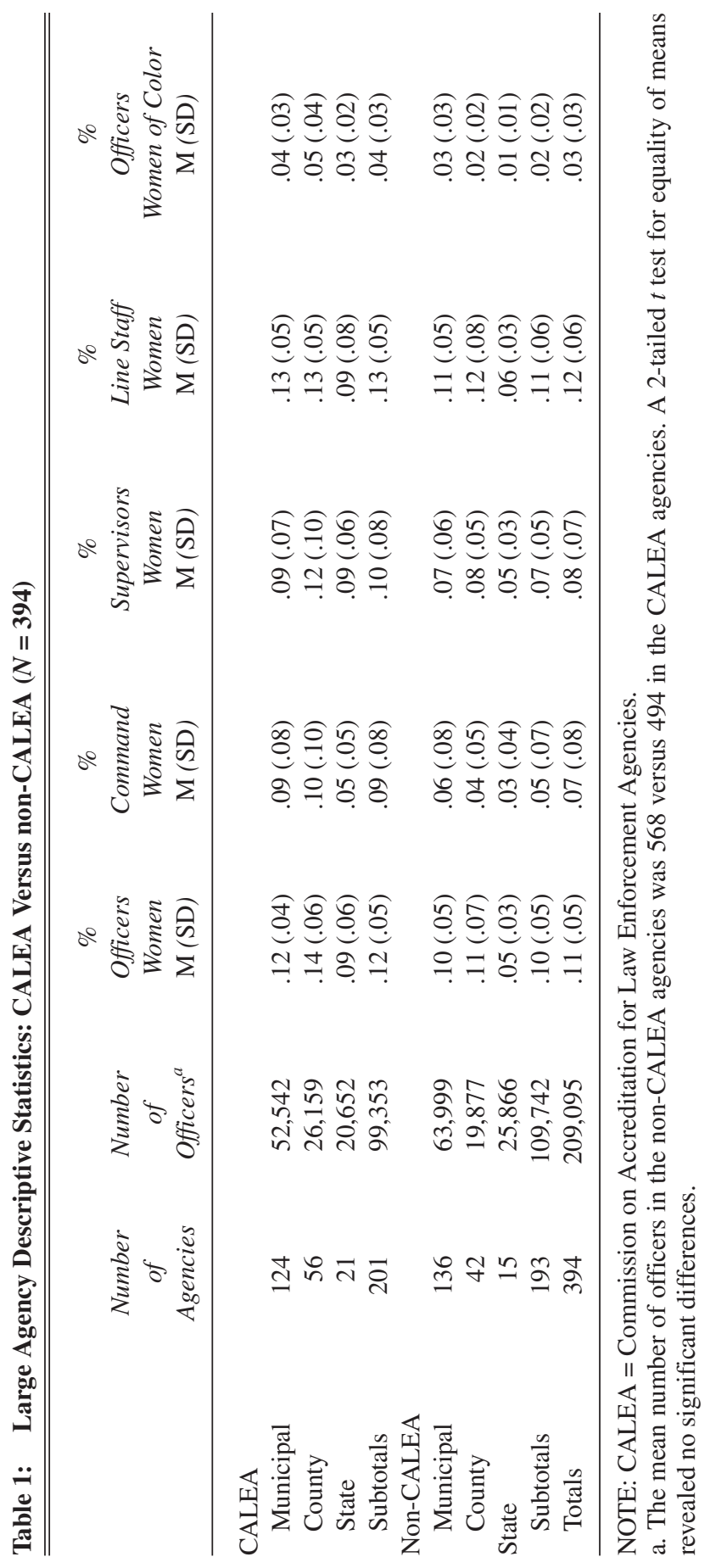


Table 2: Large Agency One-Way ANOVA: Percentages of Sworn Women by CALEA Versus non-CALEA $(N=394)$

\begin{tabular}{llllrl}
\hline \hline Percentages Women & $\begin{array}{r}\text { CALEA } \\
\mathrm{M}(\mathrm{SD})\end{array}$ & $\begin{array}{c}\text { Non-CALEA } \\
\text { W4M(SD) }\end{array}$ & df & $\mathrm{F}$ & Significance \\
\hline \% Officers women & $.12(.05)$ & $.10(.05)$ & 1 & 16.91 & $.001^{*}$ \\
\% Command women & $.09(.08)$ & $.05(.07)$ & 1 & 20.56 & $.001^{*}$ \\
\% Supervisors women & $.10(.08)$ & $.07(.05)$ & 1 & 16.84 & $.001^{*}$ \\
\% Line staff women & $.13(.05)$ & $.11(.06)$ & 1 & 9.54 & $.002^{*}$ \\
\% Officers women of color & $.04(.03)$ & $.02(.02)$ & 1 & 38.86 & $.001^{*}$ \\
\hline
\end{tabular}

NOTE: CALEA = Commission on Accreditation for Law Enforcement Agencies.

$* p<.01$. Because the Levene statistic indicated homogeneity problems in two categories, nonparametric tests (Mann-Whitney and Kolmogorov-Smirnov) were also performed. Results were significant (two-tailed) at the $p<.001$ level in all the percentages of women categories.

Table 3: Large Agency One-Way ANOVA: Percentages of Sworn Women by Type of Agency $(N=394)$

\begin{tabular}{lcccccc}
\hline \hline & $\begin{array}{c}\text { Municipal } \\
\text { Percentages Women }\end{array}$ & $\begin{array}{c}\text { County } \\
\mathrm{M}(\mathrm{SD})\end{array}$ & $\begin{array}{c}\text { State } \\
\mathrm{M}(\mathrm{SD})\end{array}$ & $\mathrm{df}$ & $\mathrm{F}$ & Significance \\
\hline \% Officers women & $.11(.05)$ & $.13(.06)$ & $.08(.06)$ & 2 & 11.49 & $.001^{* *}$ \\
\% Command women & $.08(.08)$ & $.07(.09)$ & $.04(.05)$ & 2 & 2.55 & .079 \\
\% Supervisors women & $.08(.07)$ & $.10(.09)$ & $.07(.05)$ & 2 & 3.99 & $.019^{*}$ \\
\% Line staff women & $.12(.05)$ & $.13(.06)$ & $.08(.06)$ & 2 & 10.50 & $.001^{* *}$ \\
\% Officers women of color & $.04(.03)$ & $.04(.04)$ & $.02(.02)$ & 2 & 2.71 & .068 \\
\hline
\end{tabular}

NOTE: Because the Levene statistic indicated homogeneity problems in the \% Command Women category, a nonparametric test (Kruskal-Wallis) was also performed. Results were consistent with the ANOVA result; \% Command Women was not significantly different by type of agency $\left(\chi^{2}=3.70\right.$ and Sig. $\left.=.157\right)$.

$* p<.05 . * * p<.01$.

women $(F=16.91, p>.001)$, the percentages of women at the command level $(F=20.56, p>.001)$ and at the supervisor $(F=16.84, p>.001)$ and line staff $(F=9.54, p>.002)$ levels. The difference between CALEA and non-CALEA agencies in terms of the percentages of officers who are women of color is also statistically significant $(F=38.86, p>.001)$.

A one-way ANOVA test on percentages of women by type of agency (i.e., municipal, county, or state) also revealed significant differences. As reported in Table 3 , the higher percentages in the county agencies were statistically significant in the percentages of officers who are women $(F=$ $11.49, p>.001)$ and the percentages of women at the supervisor $(F=3.99$, 
$p>.001)$ and line staff $(F=10.50, p>.001)$ levels. The type of agency did not, however, make any significant difference in the percentage of women at the command level or the percentage of women who are also women of color.

The comparisons of CALEA versus non-CALEA agencies within each of the nine U.S. Census Bureau census divisions are displayed in Table 4. One-way ANOVA tests revealed that there was at least one significant difference in the percentages of sworn women at various levels in six of the nine census divisions. In the mid-Atlantic division, there was a significant difference between CALEA and non-CALEA agencies in every category (i.e., total, command, supervisory, and line staff percentages).

\section{DISCUSSION AND CONCLUSION}

The findings suggest that there are significant differences between CALEA and non-CALEA agencies. First, there are significantly higher percentages of women in the CALEA agencies' total sworn workforces and at the line, supervisory, and command levels. Second, the CALEA agencies also have a significantly higher percentage of sworn officers who are women of color.

As previous studies (e.g., NCWP, 2002; Van Wormer \& Bartollas, 2000) indicate, the type of agency does make a difference. County agencies, regardless of CALEA involvement, had significantly higher percentages of women in the total sworn workforces and at the supervisor and line levels.

These same differences were also found in the comparisons of CALEA and non-CALEA agencies. CALEA involvement, however, also appears to generate significantly higher percentages of women commanders and percentages of sworn officers who are women of color.

Although it is logical to assume that larger agencies (i.e., those with higher numbers of sworn officers and, therefore, more budgeted positions) should have a distinct advantage in recruiting and promoting policewomen, the findings in the current study suggest that if such an advantage exists, it is not being fully pursued. There was no statistically significant difference between the CALEA and non-CALEA agencies in terms of the numbers of sworn officers; however, the CALEA agencies do have significantly larger percentages of women in all the study categories including the percentages of officers who are women of color.

The findings that there are one or more significant differences between CALEA and non-CALEA agencies in six of nine census divisions suggests that CALEA involvement, rather than demographics alone, can lead to 


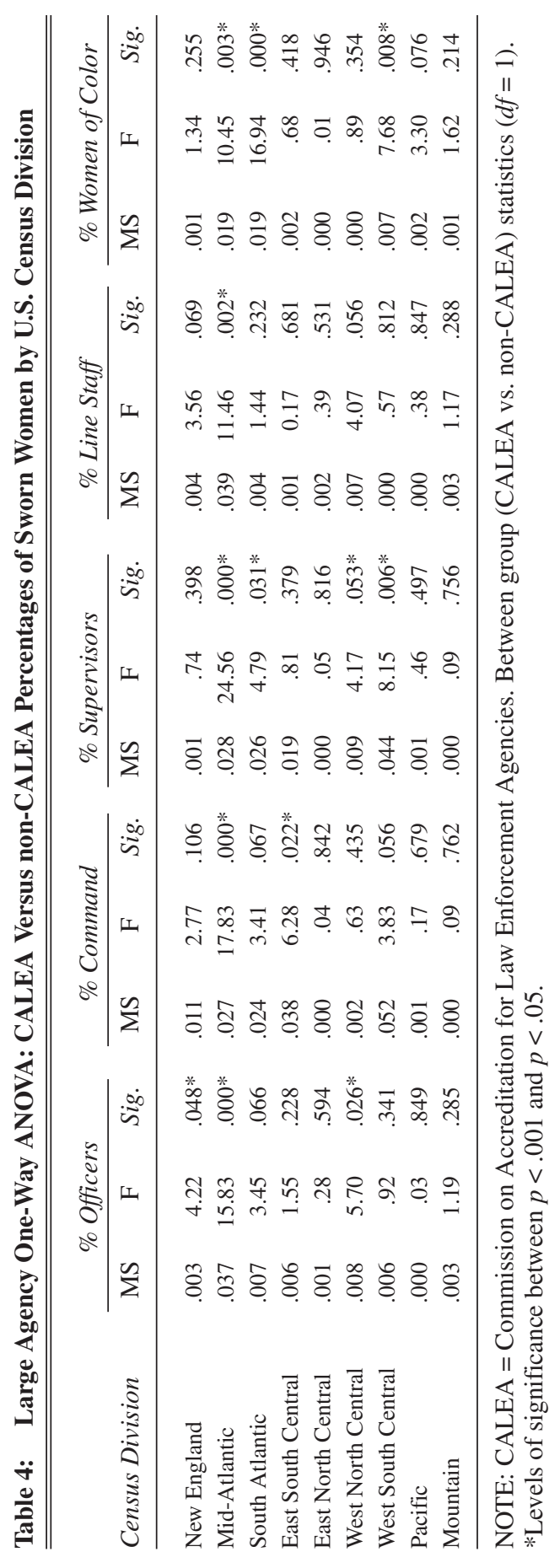


higher percentages of policewomen. This is only a suggestion, however, because a more detailed study using agreed-on available workforce data is needed before a conclusion can be drawn.

Although CALEA involvement appears to make an important difference in the recruiting and promotion of policewomen, the available workforce data used to formulate affirmative action plans are questionable. First, previously discussed changes in the labor market during the past decade suggest that the size of the female "available workforces" in many regions may have expanded well beyond the national average of 14\% that CALEA allows agencies to use in formulating affirmative action plans.

This is particularly true of the growing number of young women who are stuck in low-wage jobs with few, if any, benefits. Second, the use of $14 \%$ as an estimate of that portion of the female workforce available for and/or qualified to fill entry-level law enforcement positions by an accrediting agency implies that if an agency has at least $14 \%$ female officers, it has achieved all the female representation it needs to achieve. If such an impression is being given, it could have the result of setting an artificial ceiling on the numbers of women in law enforcement positions.

In conclusion, involvement in the CALEA accreditation process appears to encourage and facilitate the recruitment and promotion of women at least in large police agencies. We are, however, recommending that CALEA officials revisit the available workforce issue and provide agencies with additional instructions or training in obtaining more accurate estimates of the numbers of women in respective workforces who might be recruited to fill police positions.

\section{REFERENCES}

Applebaum, E., Bernhardt, A., \& Murnane, R. J. (Eds.). (2003). Low-wage America: How employers are reshaping opportunity in the workplace. New York: Russell Sage.

Bailey, K., \& Kingshott, B. (2004). Police culture, ethics, and entitlement theory. Criminal Justice Studies, 17(2), 187-202.

Baro, A., \& Burlingame, D. (1999). Law enforcement and higher education: Is there an impasse? Journal of Criminal Justice, 10(1), 57-73.

Baumol, W. J., Blinder, A. S., Wolff, E. N., \& May, J. N. (2003). Downsizing in America: Reality, causes, and consequences. New York: Russell Sage.

Belknap, J., \& Shelly, J. K. (1992). The new lone ranger: Policewomen on patrol. American Journal of Police, 12(2), 47-75.

Bennett, W. W., \& Hess, K. M. (2004). Management and supervision in law enforcement. Belmont, CA: Wadsworth. 
Bernstein, A. (2003, December 1). Waking up from the American dream: Meritocracy and equal opportunity are fading fast. Business Week, pp. 54-57.

Bernstein, J., \& Hartmann, H. (1999). Defining and characterizing the low-wage labor market. In K. Kaye \& D. S. Nightingale (Eds.), The low-wage labor market: Challenges and opportunities for economic self-sufficiency (pp. 15-40). Washington, DC: Urban Institute.

Commission on the Accreditation of Law Enforcement Agencies. (1999). Standards for law enforcement agencies (4th ed.). Fairfax, VA: Author.

Dodge, M., \& Pogrebin, M. (2001). African-American policewomen: An exploration of professional relationships. Policing, 24(4), 550-563.

Domash, S. F. (2002, May). Who wants this job? Police, 26(5), 34-35.

Felkenes, G. T., \& Schroeder, J. R. (1993). A case study of minority women in policing. Women and Criminal Justice, 4, 65-89.

Gold, M. E. (2000). The progress of women in policing. Law and Order, 48(6), 159-161.

Gossett, J. L., \& Williams, J. E. (1998). Perceived discrimination among women in law enforcement. Women and Criminal Justice, 10(1), 53-73.

Grennan, S. (2000). The past, present, and future of women in policing. In R. Muraskin (Ed.), It's a crime: Women and justice (pp. 383-398). Upper Saddle River, NJ: Prentice Hall.

Hickman, M. J., \& Reaves, B. A. (2003). Local police departments 2000. Washington, DC: Bureau of Justice Statistics.

Horne, P. (1999). Special report: Equality in policing. Law and Order, 47(11), 52-62.

International Association of Chiefs of Police. (1998). The future of women in policing: Mandates for action. Alexandria, VA: Author.

Lonsway, K., Wood, M., \& Spillar, K. (2002). Officer gender and excessive force. Law and Order, 50(12), 60-67.

Lonsway, K. A. (2001, September). The role of women in community policing: Dismantling the warrior image. Community Policing Consortium Community Links, pp. 16-17. Retrieved June 14, 2004, from www.communitypolicing.org/publications/comlinks/ c116/c116_lonsw.htm

Lonsway, K. A., \& Campbell, D. (2002). Retaining women officers. Law and Order, 50(5), 107-112.

Martin, S. E. (1991). The effectiveness of affirmative action: The case of women in policing. Justice Quarterly, 8(4), 489-504.

Martin, S. E. (1994). Outsider within the station house: The impact of race and gender on Black women police. Social Problems, 41(3), 383-400.

National Center for Women and Policing. (2001). Recruiting and retaining women: A selfassessment guide for law enforcement. Los Angeles: Author.

National Center for Women and Policing. (2002). Equality denied: The status of women in policing: 2001. Los Angeles: Author.

National Center for Women and Policing. (2003). Under scrutiny: The effect of consent decrees on the representation of women in sworn law enforcement. Los Angeles: Author.

Polisar, J., \& Milgrim, D. (1998, October). Recruiting, integrating, and retaining women police officers: Strategies that work. Police Chief, 65, 42-52.

Polk, O., \& Armstrong, D. (2001). Higher education and law enforcement career paths: Is the road to success paved by degree? Journal of Criminal Justice Education, 12(1), 77-101.

Price, B. F., \& Sokoloff, N. J. (Eds.). (2003). The criminal justice system and women (3rd ed.). Boston: McGraw-Hill. 
Prussel, D., \& Lonsway, K. A. (2001). Recruiting women police officers. Law and Order, 49(7), 91-97.

Sanow, E. (2001, July). Recruiting woes? Recruit women. Law and Order, 49(7), 4.

U. S. Census Bureau. (2002). Census 2000 equal employment opportunity file (para. 2 \& 7). Retrieved September 8, 2003, from www.census.gov/hhes/eeoindex/content.html

Van Wormer, K. S., \& Bartollas, C. (2000). Women and the criminal justice system. Boston: Allyn \& Bacon.

Warrell, G. (2000, September). Turnover: A small agency nightmare. Law and Order, 48(9), 59-61.

Zhao, J., Herbst, L., \& Lovrich, N. (2001). Race, ethnicity, and the female cop: Differential patterns of representation. Journal of Urban Affairs, 23(3/4), 243-257.

David Burlingame, MPA/JC, is a professor of criminal justice at Grand Valley State University. His research interests include law enforcement policy, women and minorities in law enforcement, and program evaluation.

Agnes L. Baro, Ph.D., is a professor of criminal justice at Valdosta State University. Her research interests include women and criminal justice, police education and training, and prison administration. 